\title{
Investigation of Different Washing Effects on Physical and Mechanical Properties of Cotton Knitted Garments
}

\author{
Solaiman', Abdur Rouf'2, Shamsuzzaman Rasel1, Elias Khalil1 \\ ${ }^{1}$ Department of Textile Engineering, World University of Bangladesh, Dhaka, Bangladesh \\ ${ }^{2}$ Department of Fashion Design and Technology, Shanto-Mariam University of Creative Technology, Dhaka, \\ Bangladesh \\ Email: solaimanbari@gmail.com,rouf_txt09@yahoo.com,shamsuzzaman_tex@yahoo.com, \\ eliaskhalil52@gmail.com
}

Received 15 September 2015; accepted 6 November 2015; published 9 November 2015

Copyright (C) 2015 by authors and Scientific Research Publishing Inc.

This work is licensed under the Creative Commons Attribution International License (CC BY). http://creativecommons.org/licenses/by/4.0/

\section{Abstract}

This paper deals with three types of washing (enzyme, softener, Silicone) effects on $100 \%$ cotton Single Jersey T-shirt, Slub Single Jersey T-shirt, Double Lacoste (5\% Lycra) Polo shirt, Single jersey CVC (T-shirt) and PC single Jersey (T-shirt). Typical industrial washing procedures and techniques were followed and then physico-mechanical properties were analyzed under standard condition. It is observed that after washing, weight of each garments has increased from $5 \%$ to $36 \%$; stitch length of the constituted fabric has decreased from $1 \%$ to $10 \%$ approximately; CPI has increased $\mathbf{2 3 \%}$ for CVC fabric only for enzyme treatment and for other process it has a little bit or no wash effects. Same effects found for WPI except $\mathbf{1 0 0 \%}$ cotton and Double Lacoste. Shrinkage property both for lengthwise and widthwise remains the same except CVC and Double Lacoste knitted garments and spirality has almost unchanged except $100 \%$ cotton and slub fabric. Both the dry and wet rubbing properties have improved after any types of wash except $100 \%$ cotton on Silicone wash. Water absorbency property has increased; $\mathrm{pH}$ of all the samples is under controlled and lies between 4.5 and 5.0. But there is no significant change of colorfastness to wash and stain after these washing treatments.

\section{Keywords}

Washing Effects, Knitted Garments, Physical and Mechanical Properties, pH, Color Fastness 


\section{Introduction}

Industrial garments washing is one of the major processes followed in the textile sector. By industrial garments washing, dust, dirt and infectious materials can be removed from garments. For improving special look on garments as per fashion requirement, a variety of wash techniques can be followed [1]. For washing of denim garments, a range of treatment methods such as enzymatic treatment [2], bleaching treatment [3] [4], acid treatment [5] [6], and Silicone treatment [7], are used widely. They all are aimed at new possible effects of fabric appearance. Particularly the dry finishing creates many effects on denim fabric; it will stimulate the customers to buy, and also it increases the market potential of the denim market [8]. Nowadays along with denim washing knit garments such as T-shirt, Polo shirt, and trouser, are washed by using different techniques as follows: enzymes wash, softener wash, Silicone wash, tie dye wash, pigment wash, caustic wash, etc. are used to create or enhance the physical and mechanical property changes [9] [10]. Enzymes are important in regulating the chemical reactions that occur within all living organisms. Without enzymes, many of these reactions would not be able to take place at a perceptible rate [11]. Fabric softener (also called fabric conditioner) is a chemical compound that prevents static cling and confers many other desirable properties to laundry that has been machine-washed. They are available as solutions and solids, sometimes impregnated in dryer sheets [12]. Silicones are polymers that include Silicone together with carbon, hydrogen, oxygen, and sometimes other elements. Some common forms include Silicone oil, Silicones grease, Silicone rubber, Silicones resin, and Silicone caulk [13]. Silicone is the second most abundant element on earth, after oxygen, making up approximately 25 percent of the earth's crust by weight; largely found in the form of oxides such as sand and clay. Sodium silicate, of formula $\mathrm{Na}_{2} \mathrm{SiO}_{3}$, is commercially produced by the reaction of soda ash and sand in a furnace [14].

This paper investigates the impact of enzymes, softener and Silicone wash on the physical and mechanical properties of knit garments as these properties determine the wearers feel and life of the end product. The paper also investigates the optimum use of enzyme with the fixed proportion of pumice stones.

\section{Methods and Materials}

\subsection{Materials}

\subsubsection{Garments Samples}

Following knits garments are used for the research purpose:

Single Jersey T-Shirt (100\% cotton) GSM 140, Single Jersey T-Shirt (Slub yarn) GSM 170, Double Lacoste Polo Shirt (5\% Lycra) GSM 228, Single Jersey T-Shirt (CVC Fabric) GSM 180, Single Jersey T-Shirt (PC Fabric) GSM 138.

\subsubsection{Chemicals}

Enzymes (RUCOLASE ZSS), Silicone (DYCHUFIX BLACK B, double components), Softener (Cationic) (Softycell IPS).

\subsubsection{Washing Machine}

AZIZ Metal Engineering Works Ltd, M/C capacity-60 kg, Max speed-50 k.m., temp $100^{\circ} \mathrm{C}$, Heating sourceSteam.

\subsection{Methods}

\subsubsection{Enzyme Wash}

At first all the five types of the knit fabrics samples are taken to the washing machine. Here material and liquor ratio is 1:5. Approximately $0.08 \%$ enzymes (RUCOLASE ZSS), $0.2 \%$ acetic acid and $0.06 \%$ detergent (WBL) is used. The washing process carried out for 15 minutes at a temperature of $45^{\circ} \mathrm{C}$. Then rinse the samples for 2 minutes. Finally tumble dryer is used to dry the fabric samples.

\subsubsection{Garments Wash (with Softener)}

At first all the five types of the knit fabrics samples are taken to the washing machine. Here material and liquor ratio is $1: 6$. Approximately $0.08 \%$ softener (Softycell IPS) is used. The washing process carried out for 10 minutes at a temperature of $60^{\circ} \mathrm{C}$. Finally tumble dryer is used to dry the fabric samples. 


\subsubsection{Silicone Wash}

At first all the five types of the knit fabrics samples are taken to the washing machine. Here material and liquor ratio is $1: 8$. Approximately $0.1 \%$ Silicone (DYCHUFIX BLACK B) is used during the process. The washing process carried out for 10 minutes at a temperature of $60^{\circ} \mathrm{C}$. Finally tumble dryer is used to dry the fabric samples.

\subsubsection{Determination of Fabric Weight}

Fabric weight was measured according to ASTM D 3776 methods of standards. We cut three pieces of the fabric with the GSM cutter (gram per square inch) and Weight the fabric with the electric balance. Then multiplied by 100 and took the average results [15].

\subsubsection{Determination of Stitch Length}

According to BS EN 14970-2006 standard we measured the stitch length. At first we count the length of the fabric in centimeter of different number of needle. Here for different types of fabric needs different number of needle count for different knit fabric. Needs 100 needles count for every type of single jersey fabrics. Needs 100 needles count for all types of Rib fabrics. Therefore Interlock need 50 needles count for stitch length measurement [16].

\subsubsection{Determination of Course per Inch (CPI)}

CPI of the fabric is calculated by counting the number of the yarn (Course) contents in 1 inch of the fabric. For this the fabric is marked by 1 inch in rectangular area. Then the yarn is open out and count the number courses contains in 1 inch [17].

\subsubsection{Determination of Wales per Inch (WPI)}

WPI of the fabric is calculated by counting the number of the yarn (Wales) contents in 1 inch of the fabric. For this the fabric is marked by 1 inch in rectangular area. Then the yarn is open out and count the number Wales contains in 1 inch [17].

\subsubsection{Determination of Shrinkage}

According to ASTM D 2259 shrinkage of these sample garments were tested. At first we Cut 3 specimens, each $50 \times 50 \mathrm{~cm}^{2}$. Then marked the fabric $35 \mathrm{~cm} \times 35 \mathrm{~cm}$, inside $50 \mathrm{~cm} \times 50 \mathrm{~cm}$ are of fabric. Then the fabric samples are boiled for 10 - 15 minutes with distilled water. After boiling tumble dryer is used to dry that fabric. Finally, length and width of the fabric sample is measured [18].

Shrinkage $\%=($ before wash - after wash $) /$ before wash .

\subsubsection{Determination of Dimensional Stability}

According ISO 3759 standards fabric samples were tested. The fabric samples were cut at a square of $50 \times 50 \mathrm{~cm}$. we laid the fabric to relax for 4 hours on a bench in ambient conditions so that it became smooth and tension free. We placed the template on the fabrics samples with the side of the template parallel to the length (warp) direction. The mark the three width and length marks in pairs $35 \mathrm{~cm}$ apart. Then draw around the edge of the template, do not round off the corners. Then we draw an arrow outside the measurement area to denote the length (warp) direction prior to cutting from the main piece. By using ECE detergent and Sodium Perborate at a temperature of $60^{\circ} \mathrm{C}$ a continuous process of washing techniques are carried out for 10 - 15 minutes. Finally we dried the fabric samples and measured the changes of dimensional stability by comparing with scale [19].

\subsubsection{Determination of Rub Property}

According to AATCC 8 standards both the dry and wet rub test were done as follows:

1) Dry rubbing test:

A test sample is clamped to the instrument base and a square of standard crocking cloth is fixed to a $16 \mathrm{~mm}$ diameter, acrylic rubbing finger. The finger rests on the sample with a pressure of 900 grams force and traverses a straight path approximately $100 \mathrm{~mm}$ long with each stroke of the arm. After testing textile materials, the crocking cloth is removed and compared against the AATCC Gray Scale for Staining or Chromatic Transference Scale. Based on this comparison, we assign a grade to the color change or amount of color transfer. 
2) Wet rubbing test:

Repeat the procedure from dry rubbing test on another sample with the white cotton test cloth wetted it in distilled water. Ensure that the rubbing test cloth will be wetted with water to $100 \%$ take up.

Compare the contrast between the untreated and treated white rubbing cloth with the staining. Grey scale rates from 1 - 5 and changing in the tested specimen with changing grey scale. This visual assessment is done in a color matching cabinet under standard lighting D-65 [20].

\subsubsection{Determination of Absorbency}

For absorbency testing we followed AATCC 79 methods of standards. Samples were placed in an embroidery hoop with all creases out of it. A burette dispenses a drop of water onto the surface of the fabric from a distance of $9.5 \mathrm{~mm}$ below the burette. Time was recorded until the water drop absorbs completely [21].

\subsubsection{Determination of pH (AATCC 81-2006)}

We conducted this test according to the AATCC 81 methods. We used $10 \mathrm{~g}$ specimen, cut into small pieces. Then Boiled $250 \mathrm{ml}$ distilled water for 10 minutes, immerse the specimen, cover the beaker with a watch glass and boiled for an additional 10 minutes. Allow the covered beaker and contents to cool down to room temperature. Finally we determined the $\mathrm{pH}$ of the extract using a $\mathrm{pH}$ meter [22].

\subsubsection{Determination of Colorfastness to Washing Test (BS EN ISO 105 C06)}

The samples were tested according to BS EN ISO 105 C06 and in the delivered condition; didn't wash and/or tumble it before testing. We used only multifibre from James Heal. The washing solution prepared freshly (one litre). The current liquor ratio (liquor/sample) is 20:1. We put the grey frame in same grey colour as background. White paper were placed as background or according to the test method one or more original multifibre to assure no transparent effect coming out of the background. The edges of the specimen and original multifibre were cut straight. The edges of the specimen and original multifibre had cut straight under defined light D65 with defined angle of $45^{\circ}$ [23].

\section{Results and Discussions}

\subsection{Effects of Fabric Weight after Washing on Different Knit Garments}

A slight increase of the GSM of all the 5 types of knit garments are found from the experiment of the different 3 types of the wash experiments. A significant amount of the GSM varies when the knit garments are applied with enzyme wash techniques though all the other washing process also affects the changes of the GSM of the knit garments. Exceptionally only GSM of the T-shirt which is composed of the CVC fibre decreases. Table 1 has shown this.

\subsection{Effects on Stitch Length after Washing of Different Knit Garments}

The following Table 2 illustrates the complete decrease of the S.L. after washing of the knit fabrics. Approximately all types of wash have the same wash effects over all types of knit garments. However, S/J 100\% cotton knit garments has the dominant changes than others.

Table 1. Effects on fabric weight after washing of different knit garments.

\begin{tabular}{cccccc}
\hline Parameters & $\begin{array}{c}\text { S/J 100\% Cotton } \\
\text { Knit Garments } \\
\text { T-Shirt }\end{array}$ & $\begin{array}{c}\text { S/J Slub Knit } \\
\text { Garments T-Shirt }\end{array}$ & $\begin{array}{c}\text { Double Lacoste 5\% } \\
\text { Lycra Knit Garments } \\
\text { Polo Shirt }\end{array}$ & $\begin{array}{c}\text { S/J CVC Knit } \\
\text { Garments T-Shirt }\end{array}$ & $\begin{array}{c}\text { S/J PC Knit } \\
\text { Garments T-Shirt }\end{array}$ \\
Before Wash & 140 & 170 & 228 & 180 & 138 \\
After Enzyme Wash & 190 & 198 & 250 & 189 & 165 \\
After Silicone Wash & 185 & 185 & 238 & 192 & 154 \\
After Softener Wash & 177 & 190 & 244 & 160 \\
\hline
\end{tabular}




\subsection{Effects on CPI after Washing of Different Knit Garments}

CPI has a great number of increment found in enzyme wash compared to all others washing process. Interestingly 23\% of the CPI increases for CVC knit fabric garments and 17\% for Double Lacoste knit fabric garments after enzyme wash. All others have a very small increment. A littile bit increment found in Silicone wash but garments wash has a very less or no increment for CPI from Figure 1.

\subsection{Effects on WPI after Washing of Different Knit Garments}

All the wash has a great amount of WPI changing effects (Figure 2). This means that these are the responsible for the increment of the fabric GSM after washing. Here CVC fabric garments has a higher amount of WPI changing effects comparing to others, second one is S/J $100 \%$ cotton knit garments.

Table 2. Effects on stitch length after washing of different knit garments.

\begin{tabular}{ccccc}
\hline Parameters & $\begin{array}{c}\text { S/J 100\% Cotton } \\
\text { Knit Garments } \\
\text { T-shirt }\end{array}$ & $\begin{array}{c}\text { S/J Slub Knit } \\
\text { Garments T-Shirt }\end{array}$ & $\begin{array}{c}\text { Double Lacoste 5\% } \\
\text { Lycra Knit Garments } \\
\text { Polo Shirt }\end{array}$ & $\begin{array}{c}\text { S/J CVC Knit } \\
\text { Garments T-Shirt }\end{array}$ \\
$\begin{array}{c}\text { G/J PC Knit } \\
\text { Gefore Wash }\end{array}$ & $29.5 \mathrm{~cm}$ & $28.5 \mathrm{~cm}$ & $33.0 \mathrm{~cm}$ & $25.5 \mathrm{~cm}$ \\
After Enzyme Wash & $26.8 \mathrm{~cm}$ & $28.0 \mathrm{~cm}$ & $31.0 \mathrm{~cm}$ & $25.0 \mathrm{~cm}$ \\
After Silicone Wash & $26.6 \mathrm{~cm}$ & $27.5 \mathrm{~cm}$ & $32.0 \mathrm{~cm}$ & $28.0 \mathrm{~cm}$ \\
After Softener Wash & $27.0 \mathrm{~cm}$ & $27.8 \mathrm{~cm}$ & $31.5 \mathrm{~cm}$ & $26.8 \mathrm{~cm}$ \\
\hline
\end{tabular}

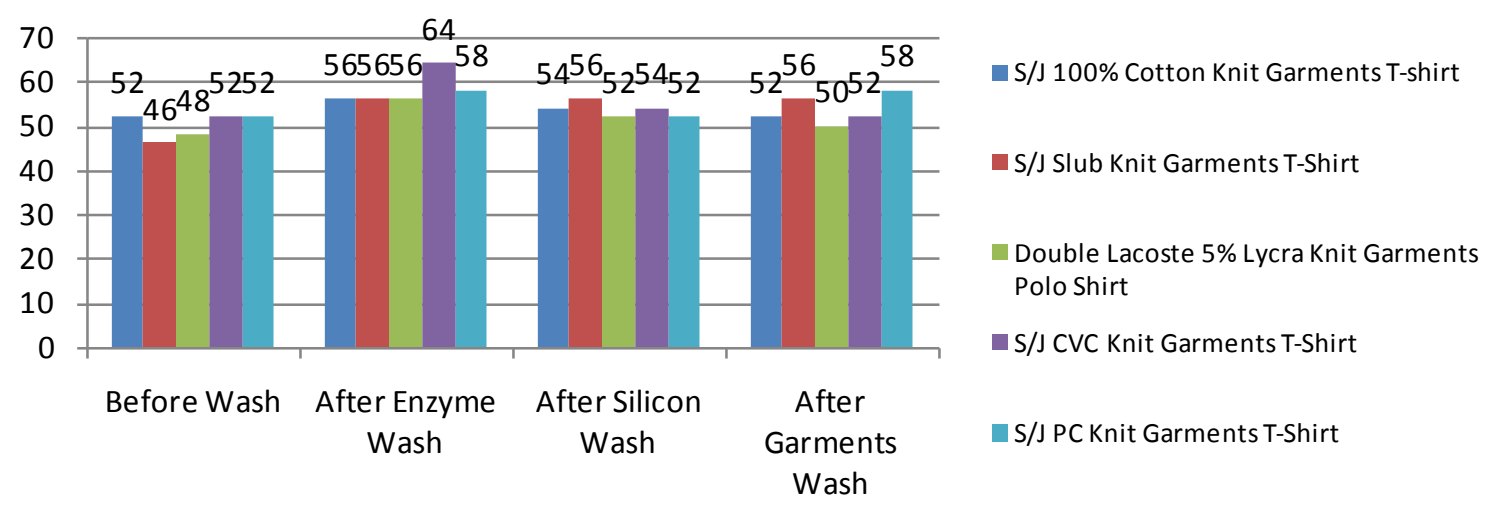

Figure 1. Effects on CPI after washing of different knit garments.

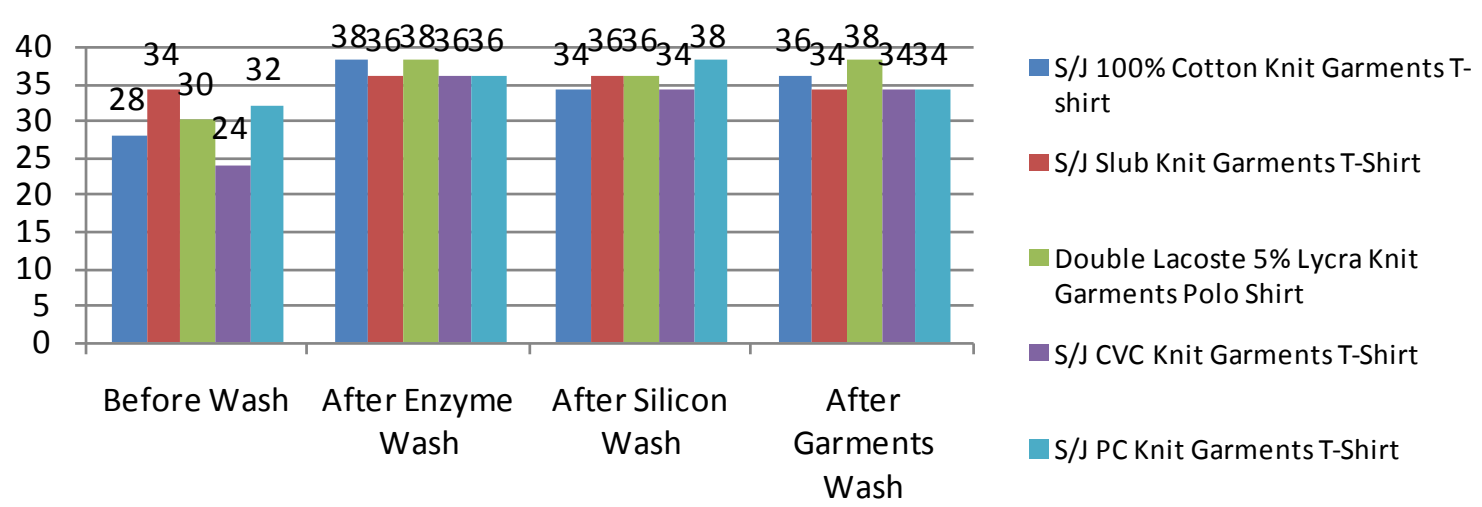

Figure 2. Effects on WPI after washing of different knit garments. 


\subsection{Effects of Shrinkages after Washing on Different Knit Garments}

A very little or no changes are found both for lengthwise and widthwise shrinkage (Table 3 and Table 4). The best quality shrinkage found for S/J Slub and PC fabric and found only 3\% of the widthwise shrinkage, whereas others shrink quality also improved. Silicone wash has a little change of shrinkage, only $3 \%$ for the fabrics but S/J 100\% cotton, D. Lacoste and PC fabric though the shrink quality compared to before wash decreases. Garments wash has a little changes of shrinkage, only $3 \%$ for the fabrics but S/J $100 \%$ cotton, D. Lacoste and PC fabric though the shrink quality compared to before wash decreases.

\subsection{Effects on Dimensional Stability after Washing of Different Knit Garments}

After enzyme wash spirality of all the fabrics increases (Table 5) which decrease the quality of knit garments. Similarly dimensional stability also increases that is the quality for the fabrics decreases after silicon wash. Also garments wash has an increment of the spirality of the fabrics but the fabrics quality remains same as it was before.

\subsection{Effects on Rub Property after Washing of Different Knit Garments}

Most of the cases rub property (Table 6) of the fabrics improved. Much improvement found for CVC fabrics. Others remains same or improved a little bit by measuring the rub property through comparing the measuring the scale.

Only a little bit changes are found when all the fabrics are under wet rub (Table 7). Though no severe changes are found but the quality of the fabrics improved.

Table 3. Effects on lengthwise shrinkage after washing on different knit garments.

\begin{tabular}{cccccc}
\hline Parameters & $\begin{array}{c}\text { S/J 100\% Cotton } \\
\text { Knit Garments } \\
\text { T-Shirt }\end{array}$ & $\begin{array}{c}\text { S/J Slub Knit } \\
\text { Garments T-Shirt }\end{array}$ & $\begin{array}{c}\text { Double Lacoste 5\% } \\
\text { Lycra Knit Garments } \\
\text { Polo Shirt }\end{array}$ & $\begin{array}{c}\text { S/J CVC Knit } \\
\text { Garments T-Shirt }\end{array}$ & $\begin{array}{c}\text { S/J PC Knit } \\
\text { Garments T-Shirt }\end{array}$ \\
\hline Before Wash & $5 \%$ & $4 \%$ & $5 \%$ & $6 \%$ & $3 \%$ \\
After Enzyme Wash & $5 \%$ & $5 \%$ & $3 \%$ & $5 \%$ & $4 \%$ \\
After Silicone Wash & $5 \%$ & $5 \%$ & $3 \%$ & $5 \%$ & $4 \%$ \\
After Softener Wash & $4 \%$ & $5 \%$ & $4 \%$ & $4.5 \%$ & $2 \%$ \\
\hline
\end{tabular}

Table 4. Effects on widthwise shrinkage after washing of different knit garments.

\begin{tabular}{|c|c|c|c|c|c|}
\hline Parameters & $\begin{array}{c}\text { S/J 100\% Cotton } \\
\text { Knit Garments } \\
\text { T-Shirt }\end{array}$ & $\begin{array}{c}\text { S/J Slub Knit } \\
\text { Garments T-Shirt }\end{array}$ & $\begin{array}{c}\text { Double Lacoste 5\% } \\
\text { Lycra Knit Garments } \\
\text { Polo Shirt }\end{array}$ & $\begin{array}{c}\text { S/J CVC Knit } \\
\text { Garments T-Shirt }\end{array}$ & $\begin{array}{c}\text { S/J PC Knit } \\
\text { Garments T-Shirt }\end{array}$ \\
\hline Before Wash & $4 \%$ & $2 \%$ & $3 \%$ & $4 \%$ & $2 \%$ \\
\hline After Enzyme Wash & $4 \%$ & $3 \%$ & $4 \%$ & $4 \%$ & $3 \%$ \\
\hline After Silicone Wash & $4 \%$ & $3 \%$ & $4 \%$ & $4 \%$ & $3 \%$ \\
\hline After Softener Wash & $4 \%$ & $3 \%$ & $3 \%$ & $4 \%$ & $3 \%$ \\
\hline
\end{tabular}

Table 5. Effects on dimensional stability after washing on different knit garments.

\begin{tabular}{|c|c|c|c|c|c|}
\hline Parameters & $\begin{array}{c}\text { S/J 100\% Cotton } \\
\text { Knit Garments } \\
\text { T-Shirt }\end{array}$ & $\begin{array}{c}\text { S/J Slub Knit } \\
\text { Garments T-Shirt }\end{array}$ & $\begin{array}{c}\text { Double Lacoste 5\% } \\
\text { Lycra Knit Garments } \\
\text { Polo Shirt }\end{array}$ & $\begin{array}{c}\text { S/J CVC Knit } \\
\text { Garments T-Shirt }\end{array}$ & $\begin{array}{c}\text { S/J PC Knit } \\
\text { Garments T-Shirt }\end{array}$ \\
\hline Before Wash & $4 \%$ & $3 \%$ & $3 \%$ & $4 \%$ & $2 \%$ \\
\hline After Enzyme Wash & $5 \%$ & $5 \%$ & $3 \%$ & $3 \%$ & $3 \%$ \\
\hline After Silicone Wash & $6 \%$ & $5 \%$ & $4 \%$ & $4 \%$ & $3 \%$ \\
\hline After Softener Wash & $5 \%$ & $4 \%$ & $3 \%$ & $4 \%$ & $3 \%$ \\
\hline
\end{tabular}


Table 6. Effects on dry rub property after washing of different knit garments.

\begin{tabular}{cccccc}
\hline Parameters & $\begin{array}{c}\text { S/J 100\% Cotton } \\
\text { Knit Garments } \\
\text { T-Shirt }\end{array}$ & $\begin{array}{c}\text { S/J Slub Knit } \\
\text { Garments T-Shirt }\end{array}$ & $\begin{array}{c}\text { Double Lacoste 5\% } \\
\text { Lycra Knit Garments } \\
\text { Polo Shirt }\end{array}$ & $\begin{array}{c}\text { S/J CVC Knit } \\
\text { Garments T-Shirt }\end{array}$ & $\begin{array}{c}\text { S/J PC Knit } \\
\text { Garments T-Shirt }\end{array}$ \\
Before Wash & 4.5 & 4.5 & 4.0 & 4.0 & 4.5 \\
After Enzyme Wash & 5.0 & 4.5 & 4.5 & 4.5 & 4.5 \\
After Silicone Wash & 4.5 & 5.0 & 4.5 & 4.5 & 5.0 \\
After Softener Wash & 5.0 & 5.0 & 4.5 & 5.0 \\
\hline
\end{tabular}

Table 7. Effects on wet rub property after washing of different knit garments.

\begin{tabular}{cccccc}
\hline Parameters & $\begin{array}{c}\text { S/J 100\% Cotton } \\
\text { Knit Garments } \\
\text { T-Shirt }\end{array}$ & $\begin{array}{c}\text { S/J Slub Knit } \\
\text { Garments T-Shirt }\end{array}$ & $\begin{array}{c}\text { Double Lacoste 5\% } \\
\text { Lycra Knit Garments } \\
\text { Polo Shirt }\end{array}$ & $\begin{array}{c}\text { S/J CVC Knit } \\
\text { Garments T-Shirt }\end{array}$ & $\begin{array}{c}\text { S/J PC Knit } \\
\text { Garments T-Shirt }\end{array}$ \\
\hline Before Wash & 4.5 & 4.0 & 3.5 & 3.5 & 4.0 \\
After Enzyme Wash & 4.5 & 5.0 & 4.0 & 4.5 & 4.5 \\
After Silicone Wash & 4.0 & 4.5 & 4.0 & 4.0 & 4.0 \\
After Softener Wash & 5.0 & 4.5 & 4.5 & 4.0 & 5.0 \\
\hline
\end{tabular}

\subsection{Effects on Absorbency after Washing of Different Knit Garments}

Absorbency of the fabrics varies a lot (Figure 3). For S/J 100\% cotton and S/J Slub fabrics absorbency decreases continuously after all other washing techniques whereas PC fabrics has a fluctuated changes of absorbency on all these 3 washing process.

\subsection{Effects on pH Value after Washing of Different Knit Garments}

$\mathrm{pH}$ has great number of changes (Table 8) than before wash for all types of wash. For enzyme wash $\mathrm{pH}$ decreases for all the fabrics but only PC fabrics has little bit increases of the $\mathrm{pH}$. Garments wash has a little bit decreases of the $\mathrm{pH}$ for first three types of the fabrics but CVC and PC has remained the same number of pH. Similar tendency found for every types of the fabrics when treated with Silicone wash.

\subsection{Effects on Color Changes after Washing of Different Knit Garments}

Color change after wash has no or a little bit changes found after washing of the fabrics (Table 9). For 100\% cotton S/J fabric has a slight improvement found when treated with Silicone but for other wash no improvement found compared to others. For Slub S/J a little color changes after all types of wash. CVC and PC have the same tendency as shown by S/J Slub fabrics. Only Double Lacoste has a slight improvement for any kinds of wash effects.

\subsection{Effects on Color Staining after Washing of Different Knit Garments}

There are no big changes founds of the color staining after wash experiment. 100\% cotton, CVC, D. Lacoste and Slub fabrics has no or a very slight changes of the color staining (from Table 10).

\section{Conclusion}

It has been found that when enzyme wash is applied on the knit garments, it improves all the tested properties of knit garments, and it also reduces the hairy fibers from the fabric surface. Similar results are found in case of Silicone and softener wash as well. Most important results are found for $100 \%$ cotton knit garments. Overall all the knit garments become improved after washing. Again with the increasingly important requirement for textile manufacturers to reduce pollution in textile production, the use of enzymes, softeners and Silicones in the 


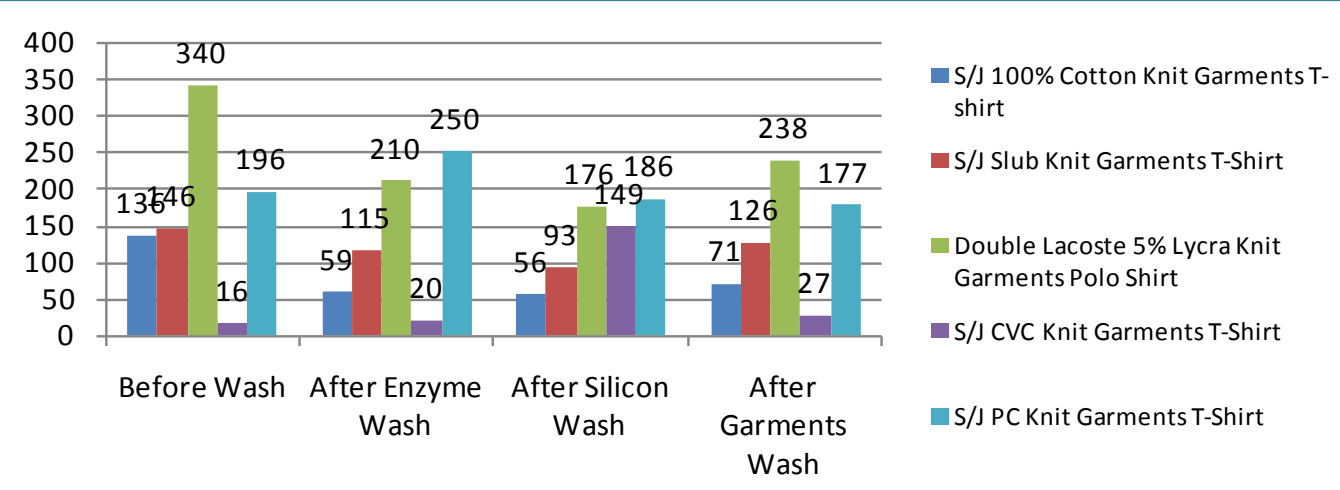

Figure 3. Effects on absorbency after washing of different knit garments.

Table 8. Effects on pH value after washing of different knit garments.

\begin{tabular}{cccccc}
\hline Parameters & $\begin{array}{c}\text { S/J 100\% Cotton } \\
\text { Knit Garments } \\
\text { T-Shirt }\end{array}$ & $\begin{array}{c}\text { S/J Slub Knit } \\
\text { Garments T-Shirt }\end{array}$ & $\begin{array}{c}\text { Double Lacoste 5\% } \\
\text { Lycra Knit Garments } \\
\text { Polo Shirt }\end{array}$ & $\begin{array}{c}\text { S/J CVC Knit } \\
\text { Garments T-Shirt }\end{array}$ & $\begin{array}{c}\text { S/J PC Knit } \\
\text { Garments T-Shirt }\end{array}$ \\
\hline Before Wash & 5.5 & 5.5 & 5.5 & 5.0 & 4.5 \\
After Enzyme Wash & 5.0 & 4.5 & 4.5 & 4.5 & 5.0 \\
After Silicone Wash & 5.0 & 4.5 & 5.0 & 5.0 & 4.5 \\
After Softener Wash & 4.5 & 4.5 & 4.5 & 5.0 & 4.5 \\
\hline
\end{tabular}

Table 9. Effects on color changes after washing of different knit garments.

\begin{tabular}{cccccc}
\hline Parameters & $\begin{array}{c}\text { S/J 100\% Cotton } \\
\text { Knit Garments } \\
\text { T-Shirt }\end{array}$ & $\begin{array}{c}\text { S/J Slub Knit } \\
\text { Garments T-Shirt }\end{array}$ & $\begin{array}{c}\text { Double Lacoste 5\% } \\
\text { Lycra Knit Garments } \\
\text { Polo Shirt }\end{array}$ & $\begin{array}{c}\text { S/J CVC Knit } \\
\text { Garments T-Shirt }\end{array}$ & $\begin{array}{c}\text { S/J PC Knit } \\
\text { Garments T-Shirt }\end{array}$ \\
\hline Before Wash & 4.5 & 5.0 & 4.0 & 4.5 & 4.5 \\
After Enzyme Wash & 4.5 & 4.5 & 4.5 & 4.5 & 4.5 \\
After Silicone Wash & 5.0 & 4.5 & 5.0 & 5.0 & 4.5 \\
After Softener Wash & 4.5 & 4.5 & 4.5 & 4.5 & 4.5 \\
\hline
\end{tabular}

Table 10. Effects on color staining after washing of different knit garments.

\begin{tabular}{cccccc}
\hline Parameters & $\begin{array}{c}\text { S/J 100\% Cotton } \\
\text { Knit Garments } \\
\text { T-Shirt }\end{array}$ & $\begin{array}{c}\text { S/J Slub Knit } \\
\text { Garments T-Shirt }\end{array}$ & $\begin{array}{c}\text { Double Lacoste 5\% } \\
\text { Lycra Knit Garments } \\
\text { Polo Shirt }\end{array}$ & $\begin{array}{c}\text { S/J CVC Knit } \\
\text { Garments T-Shirt }\end{array}$ & $\begin{array}{c}\text { S/J PC Knit } \\
\text { Garments T-Shirt }\end{array}$ \\
\hline Before Wash & 4.5 & 4.5 & 4.5 & 4.5 & 4.5 \\
After Enzyme Wash & 4.5 & 4.5 & 4.0 & 4.5 & 4.0 \\
After Silicone Wash & 4.5 & 4.5 & 5.0 & 4.5 & 4.5 \\
After Softener Wash & 4.5 & 4.5 & 4.5 & 4.5 & 4.5 \\
\hline
\end{tabular}

chemical processing of fibers and textiles is rapidly gaining wider recognition because of their non-toxic and eco-friendly characteristics. It can be used safely in a wide selection of textile processes. Nowadays application of different types of washing is increasing day by day for preparing a well good enough knit garments.

\section{References}

[1] Mondal, M.I.H. and Khan, M.M.R. (2014) Characterization and Process Optimization of Indigo Dyed Cotton Denim Garments by Enzymatic Wash. Fashion and Textiles, 1, 1-12. http://dx.doi.org/10.1186/s40691-014-0019-0 
[2] Sarkar, J., Khalil, E. and Solaiman, M. (2014) Effect of Enzyme Washing Combined with Pumice Stone on the Physical, Mechanical and Color Properties of Denim Garments. International Journal of Research in Advent Technology, 2, 65-68.

[3] Sarkar, J. and Khalil, E. (2014) Effect of Industrial Bleach Wash and Softening on the Physical, Mechanical and Color Properties of Denim Garments. IOSR Journal of Polymer and Textile Engineering, 1, 46-49. http://dx.doi.org/10.9790/019X-0134649

[4] Khan, M.M.R., Mondal, M.I.H. and Uddin, M.Z. (2011) Effect of Bleach Wash on the Physical and Mechanical Properties of Denim Garments. International Conference on Mechanical Engineering, 3.

[5] Haq, U.N. and Khan, M.M.R. (2014) Technology of Acid Wash on Woven Denim Apparel with Damp Pumice Stone.

[6] Khalil, E. (2015) Effect of Processing Time and Concentration of Potassium Permanganate on Physico-Mechanical Properties of Denim Jeans during Stone Washing. Science Innovation, 3, 68-71.

[7] Kashem, P.M. (2008) Garments Merchandising. Luckey-One Traders, Bangladesh.

[8] Khalil, E. and Islam, M.M. (2015) Wrinkle Finish on Denim by Resin Treatment: A Review. AASCIT Communication, 2, 82-87.

[9] Khalil, E., Sarkar, J., Rahman, M. and Solaiman, M. (2014) Influence of Enzyme and Silicone Wash on the PhysicoMechanical Properties of Non-Denim Twill Garments. International Journal of Scientific \& Technology Research, 3, 231-233.

[10] Gokarneshan, N., Durairaj, C., Krishnamurthy, P., Shanmugasundaram, S., Subhash, R. and Su, P. (2009) Chemical Finishing and Washing of Knit Wear. http://www.fibre2fashion.com/industry-article/23/2210/chemical-finishing-and-washing-of-knit-wear1.asp

[11] http://abyss.uoregon.edu/ js/glossary/enzyme.html

[12] Fabric Softener (2015) In Wikipedia, the Free Encyclopedia. https://en.wikipedia.org/w/index.php?title=Fabric softener\&oldid=687529481

[13] Silicone (2015) In Wikipedia, the Free Encyclopedia. https://en.wikipedia.org/w/index.php?title=Silicone\&oldid=680713579

[14] David, A.E. (2004) Immobilization of Enzymes on Nanoporous, Silica Composites.

[15] ASTM D3776/D3776M-09a (2013) Standard Test Methods for Mass per Unit Area (Weight) of Fabric. ASTM International, West Conshohocken.

[16] BS EN 14970:2006 (2006) Textiles. Knitted Fabrics. Determination of Stitch Length and Yarn Linear Density in Weft Knitted Fabrics.

[17] IS 1963 (1982) Methods for Determination of Threads per Unit Length in Knitted Fabrics. Bureau of Indian Standards, New Delhi.

[18] AATCC Test Method 96 (2009) Dimensional Changes in Commercial Laundering of Woven and Knitted Fabrics except Wool. American Association of Textile Chemists and Colorists, Research Triangle Park.

[19] ISO 3759:2011 (2011) Textiles_-Preparation, Marking and Measuring of Fabric Specimens and Garments in Tests for Determination of Dimensional Change.

[20] ISO 105-X12:2001 (2001) Textiles—Tests for Color Fastness—Part X12: Color Fastness to Rubbing.

[21] AATCC Test Method 79 (2009) Absorbency of Textiles. American Association of Textile Chemists and Colorists, AATCC Technical Manual, Research Tri U.S.A.

[22] AATCC Test Method 81-2006 (2006) pH of the Water Wet Processed Textiles. American Association of Textile Chemists and Colorists, AATCC Technical, Research Triangle Park, North Carolina.

[23] ISO 105-C10:2006 (2006) Textiles-Tests for Colour Fastness-Part C10: Colour Fastness to Washing with Soap or Soap and Soda. 